\title{
LINDA PALFREEMAN
}

University CEU Cardenal Herrera

JON ARRIZABALAGA

IMF-CSIC

Frida Stewart in Spain: administering humanitarian aid during the Spanish Civil War

\begin{abstract}
When a failed military coup provoked civil war in Spain in July 1936, the Spanish government made a worldwide plea for assistance. More than 2,500 British men answered the call, taking up arms in defence of the democratically-elected Republican government. While this show of international solidarity has been widely documented, however, much less attention has been given to the massive response made by British women. Thousands of women organized nationwide campaigns to send aid to Spain. One of these women was Frida Stewart (1910-96), a young musician with a strong social conscience. As is the case with so many other women, Frida's recollections, her memoir and correspondence, upon which the following narrative is closely based, constitute a valuable historical resource for the analysis of women's experiences during the war and give voice to those whose stories have previously gone unheard.
\end{abstract}

\section{KEY WORDS}

Spanish Civil War, humanitarian aid, ambulance, National Joint Committee for Spanish Relief (NJCSR), Frida Stewart 


\section{RESUMEN}

Cuando un fallido golpe militar provocó la guerra civil en España en julio de 1936, el gobierno español lanzó una llamada a escala mundial solicitando ayuda. Más de 2.500 hombres británicos respondieron a aquella llamada y levantaron armas en defensa del gobierno republicano democráticamente elegido. Si bien esta muestra de solidaridad internacional ha sido ampliamente documentada, se ha prestado mucha menos atención a la respuesta masiva de las mujeres británicas. Miles de mujeres organizaron campañas a nivel nacional para enviar ayuda a España. Una de estas mujeres fue Frida Stewart (1910-1996), una joven músico con una fuerte conciencia social. Como es el caso de tantas otras mujeres, los recuerdos de Frida, sus memorias y correspondencia, sobre los que se basa estrechamente la siguiente narrativa, constituyen un valioso recurso histórico para el análisis de las experiencias de las mujeres durante la guerra y dan voz a aquéllas cuyas historias han ido sin ser escuchadas.

\section{PALABRAS CLAVE}

Guerra Civil española, ayuda humanitaria, ambulancia, National Joint Committee for Spanish Relief (NJCSR), Frida Stewart 


\section{INTRODUCTION}

Traditional approaches to the study of humanitarian aid have tended to focus on the achievements of the international collectives involved, paying scant attention to the actions and experiences of the individuals of whom these agencies were comprised. More recent studies, however, question this approach, concentrating instead on the individual actors responsible for administering aid in the field (Taithe 1998, 1999; Gill 2013; Martín-Moruño et al. 2020). In addition to any corresponding official reports, such works examine a range of other materials including private letters, diaries and memoirs of the individuals involved. This methodological approach is adopted in the present study in which the narrative is based closely on the private correspondence and unpublished memoir of Frida Stewart (1944) and on an interview held with her at her home in Cambridge (United Kingdom) in 1986.

Up until recently, the historiography of humanitarian aid has also displayed a marked underrepresentation of women and a failure to acknowledge the magnitude of female participation and its meaning from a gender perspective (Green 2014: 1157). With a few notable exceptions (Fyrth and Alexander 1991; Jackson 2012; Derby 2015), histories of Britons' response to the Spanish Civil War have focused overwhelmingly on men. More than 2,500 British men volunteered to fight with the International Brigades in defence of the democratically-elected Republican government. British women also responded on a massive scale. In a show of solidarity and commitment hitherto unprecedented in the male-dominated political arena, women crossed all political party borders in support of the Second Republic and were able to galvanize the British public to take an active part in that support (Buchanan 1997: 65). Their diaries, memoirs and autobiographies constitute a valuable historical source for the analysis of women's experiences during the war, giving voice to those whose stories have, in the 
most classic historical sources, previously gone unheard. They are stories that may shed little new light on much publicized events but, rather, disclose the individual's perceptions and experiences, thoughts and feelings, as well as details of their particular social activism. Whilst they inevitably reveal gaps and contradictions, these personal testimonies are inextricably linked to cultural, social and political history and, in particular, to the history of women and gender. They play a crucial part in reconstructing the role of women during war and post-war periods (Martín-Moruño and Ordóñez 2010; Arrizabalaga 2019a, 2019b; Martínez-Vidal 2020).

The Spanish Civil War saw the increased politicization and expansion of women's organizations, reshaping the identity of women and marking a turning point in relation to their presence in the public sphere, both inside and outside Spain. British women activists during the Spanish Civil War were part of an incipient gendered solidarity being forged across national and political boundaries in order to challenge forms of oppression within the political realm.

Revisiting history from the perspective of gender can increase our understanding of events and, more notably, of power relations. It does not imply that the women involved were feminists nor does it suggest that their work should be interpreted as part of a conscious attempt to escape the bounds of the prevalent Imperialist feminism (Burton 1994: 1-32). Sometimes, a gender perspective is adopted merely to debunk the mythical representation of women in the history of humanitarian relief as 'loving angels or compassionate mothers' (Martín-Moruño 2017: 21). The humanitarian role played by Frida Stewart (1910-96) in the Spanish Civil War is a case in point. While Stewart makes no explicit reference to gender distinctions in her account of her fight against fascism, her involvement in the Spanish conflict reflects a desire to play a more active role than traditional notions of femininity would permit. 


\section{THE OUTBREAK OF CIVIL WAR IN SPAIN, JULY 1936}

In February 1936, a general election in Spain gave a clear parliamentary majority to the left-wing coalition called the Popular Front. As the newly-elected government began to implement liberal reforms, right-wing generals began plotting a military uprising against it. Attempts were made to negotiate a peaceful outcome with the insurgent generals, but with the latter bolstered by the support of the powerful fascist forces of Germany and Italy, negotiations failed and on 18 July 1936 the bloodshed began. This was the beginning of a long and bloody civil war (Preston 2006).

The British government declared a policy of non-intervention in Spain. The chief reasons given were the wish to prevent the Spanish Civil War from becoming a widespread European conflict and also to avoid risking British involvement in a war in which it was ill-equipped to fight (Thomas 1961: 257). Many thousands of British citizens, however, launched a campaign of fierce support for the democratically-elected Republican government. While more than 2,500 British volunteers enlisted in the International Brigades to fight for the Republic (Baxell 2007: 18), many thousands more launched fundraising events in order to send humanitarian aid to Spain (Fyrth 1986: 3342; Buchanan 1997: 93-120). Many of these were women, from all walks of life and social circumstance. Some of the women at the forefront of the Aid to Spain movement were prominent politicians, and included representatives from all major parties: Conservative MPs such as the Duchess of Atholl; Labour representatives including Ellen Wilkinson and Leah Manning; and the communist activist, Isabel Brown, who chaired the British Committee for Aid to Victims of Fascism. In a show of solidarity and mutual commitment, hitherto unprecedented in the male-dominated political arena, these women crossed all borders of political parties in support of the Republic, and were able to galvanize the British public to take an active part in that support. They organized all 
kinds of fundraising events, from lectures and book clubs to flea markets and cake sales, to send humanitarian aid to Spain (Fyrth 1986: 20-23). Many of these women, including Stewart, saw the Republican struggle in Spain as a vital opportunity to stop the wave of fascism that was sweeping across Europe in the 1930s.

Despite its policy of non-intervention in the Spanish conflict, the British government made significant contributions to humanitarian aid (Buchanan 1997: 95). Aid was needed on such a scale, however, that many new organizations were established specifically for this purpose. Anti-fascist movements, peace organizations and political and religious groups all came out in support of the Spanish government. There was some aid sent from Britain to the rebel forces, but fundraising activities on their behalf were confined almost exclusively to the Roman Catholic community and were short-lived (Palfreeman 2012: 3). Buchanan sums up the reaction of the British people:

Fascism, in its many forms, appeared to offer a terrifying threat to democracy and to civilization itself. Thus, the outbreak of the Spanish Civil War in July 1936 was seized upon by many as the first occasion where fascism had been resisted by a people in arms, and provided a lesson in how this thuggish, nationalistic, and dictatorial force could be stopped. Moreover, they believed that, if Franco and his Fascist backers could be defeated in Spain, then countries such as Britain could be spared a similar ordeal.

(Buchanan 1997: 3)

It was this very sentiment that led young British woman, Frida Stewart, to throw herself into humanitarian relief work for the Spanish people, as a representative of the National Joint Committee for Spanish Relief (NJCSR). The Liberal MP, Wilfrid Roberts, inspired the creation of the committee, but its members were of every political inclination and reflected a wide variety of humanitarian interests. It was chaired by Conservative MP, the Duchess of Atholl, and its various cooperating societies included the Social Service 
Council of the Society of Friends and the Save the Children Fund. Its aim was to prevent the overlapping of the many different appeals that had been established and to facilitate the efficient collection and allocation of funds, as well as the dispatch of other material help to Spain. The work of the committee was divided into three basic areas: the care of refugees, the removal of civilians from battle areas and medical aid. The NJCSR declared its intent:

[...] to relieve the suffering of children, of civilians, helpless in the face of modern war, of the sick and the wounded. We believe that whatever divergent political views may be held on the conflict itself, the urgency of the need is so great that no one can question the necessity for action.

(National Joint Committee for Spanish Relief 1937)

\section{FRIDA STEWART'S POLITICAL AWAKENING}

Frideswide Frances Emma Stewart, or Frida Stewart, as she preferred, was one of five children and grew up in the heart of a happy, comfortably-off family in Cambridge, where her father, Hugh Fraser Stewart, was Dean of Trinity College. Whereas her siblings were all academically-inclined, Frida preferred music and nature and was considered something of a rebel. She reached adolescence, she recalls, 'unaffected by the family's discouraging comments on my shocking school reports and fortified by a clear vision of a glorious career as a super-musico-ornithologist' (Stewart 1944: 2).

Frida's mother, Jessie Stewart, was one of the first generation of women to study at Newnham College, Cambridge. She had a strong social conscience and was a devoted champion of various good causes, working in aid of refugees, in fighting poverty and, generally, in striving to make a better world (Jackson 2012: 31). She encouraged Frida's free and rebellious spirit, her sense of social justice and her humanitarian principles. One of Frida's earliest recollections was of a garden party in the grounds of her 
grandfather's house, when she was about six years old. The British Red Cross took some soldiers who had been wounded in the First World War. She was deeply moved by the sight of the maimed men:

[S]ome had an arm missing, or a bandaged head, and were pushed about in wheel-chairs, others limped on crutches having lost a foot or a leg at the Front $[\ldots]$ the sight of the mutilated spectators in blue spoiled all my youthful pleasure in the afternoon.

(Stewart 1944: 7)

Though very young, Stewart became aware of the terrible suffering caused by the war, and resolved to do whatever she could to speed its conclusion:

[A]s my eighth birthday approached I began to add a special plea to God to arrange for the war to end that day [...] I redoubled my pressure on God and, when the news came through on the $11^{\text {th }}$ at midday that the Armistice had been signed that morning, I felt immensely responsible and as important as if it had been all my own work.

(Stewart 1944: 7-8)

Ill-health meant that much of Stewart's education was carried out at home, where she pursued her love of music and literature, eventually going on to study violin at the Royal College of Music. While finishing her studies in Frankfurt in 1928, she witnessed the rise of fascism which sharpened her political awareness. This was consolidated further when she worked at the Manchester University Settlement in Ancoats, producing music and plays with the unemployed. Stewart admired the good humour and resilience of those among whom she worked - people living in desperate poverty circumstances which, she was acutely aware, contrasted sharply with her own privileged upbringing. Stewart was then employed by Yorkshire County Council in conjunction with Hull University College on a programme for presenting drama and opera in rural 
areas. She enjoyed the work but became increasingly troubled by the rise of fascism and particularly by the situation in Spain.

Stewart began to work for the NJCSR and established an Aid Spain Committee, persuading the Archbishop of York, William Temple, to be chairman. Like hundreds of other committees around the country, they held meetings, organized fêtes and film shows and other events to raise money for the Republican cause (Fyrth 1986: 203-04). Her work for the NJCSR became an important part of Stewart's life, but she desperately wanted to go to Spain, to be of use where it mattered and 'cherished the idea of joining the International Brigades' (Stewart 1986). However, she dismissed the ideas of 'nursing or bottle-washing or stretcher-carrying' as the only acceptable (female) roles open to her at that time (Stewart 1944: 112).

When, in February 1937, Sir George Young (1908-60) asked Stewart to drive out an ambulance to southern Spain, she 'gladly accepted the offer' (Stewart 1986). It was at this point that she decided to 'go the whole hog and join the Communist Party' (Stewart in Jackson 2012: 68). Like many other British defenders of Spanish democracy, she was disappointed with the Labour Party's apathetic response to the Spanish crisis and joining the Communist Party seemed the only politically appropriate thing to do (Baxell 2012: 20-21). As Jackson points out, Party membership was one of the ways in which women could demonstrate their support for the Spanish Republic: 'women could see in Spain a new focus for their energies. Spain was the clarion call that offered an opportunity to which they could respond, whatever the mixture of the personal, the ideological, the humanitarian and the political on which their motivation was founded' (Jackson 2012: 69). This was certainly the case with Stewart:

It was the great hopeful time of our lives - we really felt it was the turning point between the world going over to the fascists or becoming a brave, new world, or 
at least avoiding a world war, which was obviously going to happen if the Germans and the Italians tried out their methods and over-ran Spain.

(Stewart cited in Jackson 1996: 2)

As we shall see, women's work in Murcia turned out to be less of a revolutionary nature than she might have hoped or expected. Meanwhile, her excitement at the prospect of going to Spain was subdued only by the thought of the anxiety that it might cause her mother. Nevertheless, she knew that her mother would not disprove of her decision:

I think she knew me well enough to know that I wouldn't be quite mad and do totally idiotic things, she trusted me to look after myself. And she knew from her own background - if you wanted something and you felt you could do it, you had to do it. She'd gone - was one of the very early Newnham students in the face of a lot of resistance from her family.

(Stewart cited in Jackson 2012: 129)

Sir George Young, an authority on Spanish history and politics, followed closely as events unfolded in Spain. The uprising had been quashed in the southern coastal city of Malaga and in most of the surrounding province, but as the enemy approached, Francoist General Queipo de Llano's vile threats of revenge became more of an imminent reality and many saw fleeing the city as their only hope of survival (Preston 2012: 132-78). Anticipating the need for medical assistance and other humanitarian aid, Young hastened to put the finishing touches to his plan to take out an ambulance unit. However, before they reached southern Spain, Malaga had been occupied.

While the rebels unleashed unspeakable brutality on those remaining in the city, many thousands of citizens fled. This desperate move was to involve them in what would become one of the most sickening atrocities of the entire conflict, as they set out on the arduous journey eastwards to the city of Almeria (Beevor 2006: 201; Preston 2012: 176-78). The great majority had to make the 200-kilometre trek on foot along hilly coastal tracks carrying bags and bundles of worldly possessions, with little or no 
food and scant protection from the winter cold. The stream of refugees provided an easy target for the aerial attacks of Franco's fascist allies and from battleships trained on the coastline, and they were forced to sleep during the day and walk at night, eating whatever plants and herbs they could find to stave off their hunger (Palfreeman 2013: 169-70).

Despite indescribable adversity, more than 80,000 people managed to reach Almeria; some 20,000 made their way back to Malaga, and more than 5,000 were shot or died of hardship and starvation along the way (Young 1937: 2). Almeria was illprepared to cope with the massive influx of people and there was urgent need for assistance from outside. Within a week, Sir George Young's University Ambulance Unit was on its way to southern Spain. Even before securing quarters for themselves, the volunteers set up feeding stations and aid posts for refugees in Almeria, and eventually established hospitals for the sick and suffering children among them (Palfreeman 2013: 147-48).

\section{STEWART JOINS IN THE SPANISH STRUGGLE}

Stewart resigned from her job with Hull University. 'I said I was sorry but, in truth, this did not break my heart which was in the Spanish struggle, and while that continued I realized I would never feel enthusiastic enough about the classes to make a really good job of them' (Stewart 1944: 113). Together with the young Irish woman, Kathleen McColgan, and elderly nurse Shaw, Stewart drove the ambulance through the London streets to cheers from sympathetic onlookers. McColgan, an Oxford graduate, volunteered as a general relief worker. Nurse Shaw had cared for typhoid patients during a recent epidemic in Bournemouth and would be of valuable help with the many typhoid cases now presenting among the refugees (Fyrth 1986: 168). By the time they reached Murcia, in May 1937, the city's population had almost doubled and many of the 
refugees were herded together in miserable conditions in makeshift refugios. Aid worker Francesca Wilson was in Spain on behalf of the Society of Friends. She introduced Stewart to the refuge 'Pablo Iglesias', one of five such shelters in the city:

The first impression of the centre was quite unforgettable - the stench that assailed you as you approached the entrance, the sight of the muck heaps and piles of rusty rubbish and refuse, and of the ragged people sitting and leaning in the doorway, the filthy, bony little children crawling about in the semi-darkness of the interior. It was all like something out of Dickens at his most sordid, hardly believable that it could exist in 1937 [...] The dirt and degradation made me feel quite sick with anger.

(Stewart 1944: 126)

With foodstuffs sent by the Friends' Service Council, Wilson set about providing breakfasts for the refuge's inmates. She organized helpers for each centre, to hand out food and soap, while others set up classes for the children who were 'running wild' in the refugios. Sewing workshops were also established, with donated equipment and materials, to provide useful employment (and much-needed clothing) for the refugee women. Some had fled their homes with nothing more than the clothes they were wearing, and there were no facilities for washing - or soap, even if there was water available (Wilson 1944: 174).

Many of the children arrived from the flight from Malaga exhausted and undernourished. A great many of them needed hospital care, but with the civilian hospital in Murcia packed to the limit, the only solution was to create a new hospital. Thanks to the intervention of the mayor, a large, well-appointed villa was requisitioned for the purpose. The local shops contributed medicines and equipment of all kinds and everyone who could gave help (Wilson 1944: 183). 
At first, Stewart and Wilson drove around the refugios with a huge hotel bus, collecting the sick children and taking them to the hospital for examination (Stewart 1986). When mothers saw that the infants were being well cared-for, patients began to pour in, the most prevalent illnesses being pneumonia and bronchitis. Although at first, several of the very weakest babies died, many of the infants responded quickly to nursing care, as Wilson explains: 'Most of the children recovered and after three or four weeks were sitting in the garden, thin as skeletons but cheerful and with ravenous appetites' (1944: 184).

While the coming of the Republic had promised progress in terms of female emancipation, the reality encountered by Stewart, and other volunteers in Spain, was somewhat different. During the initial days of the conflict, milicianas fought at the battlefront, shoulder-to-shoulder with their male comrades, but these were few (five milicianas in Murcia joined the Columna Tomás López) and women were soon restricted, once again, to the more traditional roles allotted them. The antifascist cry became: 'Hombres al frente, Mujeres a la Retaguardia' (Men to the front, women to the rear) (Nash 1986: 104-17).

There were Agrupaciones de Mujeres Antifascistas established throughout Republican Spain. Their members included women of diverse social classes and of different left-wing political ideologies, mainly communists. They were united in the belief that the antifascist fight took precedence over the fight for gender equality. 'Mujeres Anfifascistas never questioned the division of gender roles, and there was abundant reference to their traditional functions of mother, wife and daughter', affirms González (1999: 140). Any attempts by its members to question this position were met with public condemnation by the association itself (González 1999: 143). Such was the state of affairs in Murcia when Stewart joined the antifascist fight and it would appear 
that she embraced her situation without protest. At least no such protest has been registered in her writings or in her later interviews after the war. However, Stewart was keen to expand her experience of wartime work.

When a badly poisoned hand prevented Stewart from working at the hospital, she persuaded a lorry driver carrying supplies to give her a lift to Madrid (Stewart 1944: 139). Once her hand had healed, she found typing work at the Press Office among the noted journalists Sefton Delmer, Frank Pitcairn, Robert Capa and Gerda Taro. She worked for Canadian journalist Ted Allen for some weeks and then for renowned American journalist Anna Louise Strong. During this time, Stewart made several radio broadcasts to try to convey to people in England the desperate situation in the Spanish capital (Jackson 2012: 224).

Stewart was also given the task of editing a Spanish grammar and vocabulary book for British and American International Brigaders. This was not work that she found entirely inspiring, as it required the translation of countless phrases such as: 'Pass the amo, quick,' and 'My gun lock is rusty' (Stewart 1944: 167). Eventually, Stewart succumbed to her family's pleas for her to return home. However, this would not be the end of her work for Spain.

\section{WORK WITH THE BASQUE CHILDREN IN BRITAIN}

By April 1937, Nationalist (rebel) troops had closed in on Bilbao and the Basque government made a worldwide appeal for help in evacuating its children. After lengthy negotiations with the British government, the NJCSR was finally given permission to bring 4,000 children to Britain (Bell 2007: 7). The Basque Children's Committee was formed to organize the expedition and to fund and oversee their care (Bell 2007; Fyrth 1986: 220-42). As an urgent interim measure, until more permanent homes could be arranged, a campsite was hurriedly prepared in Eastleigh, Southampton, and hundreds 
of willing volunteers were recruited to run it. A massive voluntary effort was also made by the local community, including groups of students, Boy Scouts, Guides, and YMCA members, who erected 200 tents and three marquees brought in by the Army (Fyrth 1986: 224). The camp eventually closed down in September, when the last of the children had been homed. Wherever there was a group of children needing a home, NJCSR volunteers formed a committee, found accommodation and undertook to look after them.

By the time Stewart got back to England, the homes were organized and staffed, but the NJCSR had a particular role in mind for her:

The National Joint Committee was not averse to combining propaganda with child welfare, and gave me a dual job which covered both aspects of the committee's work; on the one hand I had to visit the Basque homes and to report to London on their welfare and needs, after talking to staff, children and señoritas (that I spoke Spanish was my chief, perhaps my only, qualification); on the other hand I had to try to raise money by organizing meetings, with speakers on the Spanish question, and concerts at which the children themselves would perform.

(Stewart 1944: 157-58)

The NJCSR took full advantage of the children's artistic talents in its fundraising tactics. Basque Children's Concert Parties were formed in almost every home and events were held around the country. This kept the children in the public eye, aroused affection for them and helped raise money towards their upkeep. They performed traditional Basque songs, dressed in the national costumes made by their Spanish chaperones (or señoritas) and other volunteers (Fyrth 1986: 220-42). The Salvation Army also taught them to sing English songs like 'Jesus wants me for a sun beam' which, recalled Stewart later, invariably brought the house down (Stewart 1986). 
Stewart called on many old colleagues, friends and family contacts to help with concert venues, costumes and transport. She even organized successful trips abroad (Stewart 1944: 190). After the fall of Bilbao and Franco's capture of the rest of northern Spain in the summer of 1937 , the process of repatriation began - a sorrowful period that would leave a lifelong impression on Stewart.

\section{THE FALL OF THE SPANISH REPUBLIC}

When Barcelona finally fell to the Nationalist insurgents, thousands of people, both civilians and soldiers, fled north towards France in what would become known as the retirada (Alted 2005: 42-43). Along with them went representatives of the NJCSR who had been working in the city. For Stewart, at home in England, the news came as a terrible blow (Stewart 1986). As nearly half a million refugees made their way towards the French border, aid workers set up tents and makeshift shelters by the roadside from which to distribute food and provide emergency medical care. Once the NJCSR had set up headquarters in Perpignan, Stewart explained how she 'moved heaven and earth - in other words, the heads of our Committee to be sent out as a volunteer' (Stewart 1944: 176).

In collaboration with the Quakers of the International Commission, the NJCSR gave assistance to the refugees in France, both to the women and children who were interned in camps scattered throughout the country and the hundreds of thousands of men who were held in makeshift camps, in dreadful conditions, along the southern French coast. Stewart and her fellow relief workers provided both material aid and moral support. They were also instrumental in helping many people to escape the horror of life in the camps (Alted 2005: 42-43). Some refugees found local employment, whilst others were evacuated further afield. The most successful evacuation was that effected on 24 May 1939, at the initiative of the NJCSR in collaboration with the 
Society of Friends, when the Sinaia ship took 2,000 refugees from Sète to begin a new life in Veracruz, Mexico (Fyrth 1986: 299).

When her work for the NJCSR was over, Stewart went to Paris where, despite being aware of the imminent German invasion, she enrolled as a student at the Sorbonne. When invasion came in June 1940, she was imprisoned and spent almost a year in Nazi internment camps until she managed to escape. Using forged papers provided by the Resistance, she and a friend eventually made it back to Britain, carrying a top-secret message for General de Gaulle (Stewart 1986). She then worked with the Free French organization in London (Stewart 1942: 99). In 1944, Stewart married microbiologist B. C. J. G. Knight, later professor of Microbiology at Reading University, with whom she had four children. She published numerous books under her married name, including a study of the French Resistance (Knight 1975) and a biography of Beethoven (Knight 1973), one of several musical biographies.

A perpetual activist, Frida Knight (as she was now known) was a founding member of the Cambridge Peace Council and co-founder and chair of the Cuba Solidarity Campaign. She was also a long-time member of the Campaign for Nuclear Disarmament (CND) and supporter of the United Nations Association. In her senior years, she chaired the local Morning Star Readers' and Supporters' Group and remained a stalwart member of the Communist Party of Great Britain until its dissolution (Stewart 1986). Nevertheless, it was Spain that had loomed largest in Frida's life. When sorting through Frida's personal papers, after her death, historian Angela Jackson discovered just how important Spain had been to her:

On an old scrap of paper, undated but written in the rather shaky handwriting of her later years, is a brief summary of her life which begins: 'The most significant 
moment in my life was the day the ambulance took me across the border into Spain'.

(Jackson 2012: 308)

Frida Knight died on 2 October 1996, a month before her 86th birthday.

\section{CONCLUSIONS}

In analyzing Frida Stewart's involvement in humanitarian activities during the Spanish Civil War, it is important to consider the question of her identity as a woman. On the one hand, her indefatigable activism fits that traditionally associated with women, beginning with the rousing of compassion and the mobilizing of support for civilian victims of the war. This pattern continues in her work with the civilian population (mostly women and children) in Murcia; in the reception of the Basque children evacuated to Great Britain; and, finally, in the care of the Spanish refugees detained in internment camps in southern France at the end of the war.

The other side of Stewart's humanitarian activism openly broke with the established gender model, invading spaces traditionally reserved for men, not only with respect to the activities involved (ambulance driver, journalist, radio host, negotiator for the NJCSR, missions to support the Resistance, etc.), but also for the audacity and determination with which these enterprises were carried out. She engaged progressively more directly with the political and military actors of the conflict, as her communist political identity became consolidated. As in the case of so many other communist women, Stewart's revolutionary impetus led her to concede the subordination of women's affairs to the international revolutionary cause (Nash 1995: 48-97).

Frida's family role-models, especially her mother, undoubtedly played a crucial role in shaping her independent spirit and her humanitarian principles. Direct experience 
of the human drama being played out in Spain radicalized her political position (as it did with many volunteers), leading her towards communist militancy. This faith, in which Frida firmly believed until the end, made her feel part of an international movement which detached her from her own social class and led her to combine family life with commitment to several political, social and civic causes in Britain, Europe and the rest of the world.

\section{REFERENCES}

Alted, A. (2005), La voz de los vencidos. El exilio republicano de 1939, Madrid: Aguilar.

Arrizabalaga, J. (2019a), "The "merciful and loving sex": Concepción Arenal's narratives on Spanish Red Cross women's war relief work in the 1870s', Medicine, Conflict and Survival, 7 Oct, pp. 1-21: https://doi.org/10.1080/13623699.2019.1678649

(2019b), 'Performing population's humanitarian emotions in wartime: Narratives of Relief Action in the Spanish Civil Wars during the 1870s', in D. MartínMoruño and B. Pichel (eds.), Emotional Bodies: The Historical Performativity of Emotions, Urbana \& Champaign: University of Illinois Press, pp. 199-218.

Baxell, R. (2007), British Volunteers in the Spanish Civil War, Pontypool: Warren \& Pell Publishing.

(2012), Unlikely Warriors: the British in the Spanish Civil War and the Struggle against Fascism, London: Aurum Press Ltd.

Beevor, A. (2006), The Battle for Spain: The Spanish Civil War 1936-1939, London: Penguin Books.

Bell, A. (2007), Only for Three Months: The Basque Children in Exile, Norwich: Mousehold Press.

Buchanan, T. (1997), Britain and the Spanish Civil War, Cambridge: Cambridge University Press.

Burton, A. M. (1994), Burdens of History: British Feminists, Indian Women, and Imperial Culture, 1865-1915, Chapel Hill: University of North Carolina Press.

Derby, M. (2015), Petals and Bullets. New Zealand Nurse in the Spanish Civil War, Brighton: Cañada Blanch/Sussex Academic Studies.

Fyrth, J. (1986), 'The signal was Spain'. The Aid Spain Movement in Britain, 19361939, London: Lawrence \& Wishart. 
Fyrth, J. and Alexander, S. (eds.) (1991), Women's Voices from the Spanish Civil War, London: Lawrence \& Wishart.

Gill, R. (2013), Calculating Compassion: Humanity and Relief in War, Britain 18701914, Manchester: Manchester University Press.

González, M. C. (1999), Guerra Civil en Murcia: un análisis sobre el poder y los comportamientos colectivos, Murcia: Universidad de Murcia.

Green, A. (2014), 'Humanitarianism in nineteenth-century context: religious, gendered, national', The Historical Journal, 57:4, pp. 1157-75, https://ora.ox.ac.uk/objects/uuid:7927879f-b8d7-4770-a485aeb53b0b9843/download file?file format $=$ pdf\&safe filename $=$ Green Humanitarianis m.pdf\&type of work =Journal + article

Jackson, A. (1996), 'A celebration of the life and work of Frida Knight 11 Nov. 1910 2 Oct. 1996’. (Unpublished pamphlet).

(2012), British Women and the Spanish Civil War, London: Routledge/Cañada Blanch Studies on Contemporary Spain.

Knight, F. (1973), Beethoven and the Age of Revolution, New York: International Publishers.

Wishart.

(1975), The French Resistance, 1940 to 1944, London: Lawrence and

Martín-Moruño, D. (2017), 'Tejiendo redes de cuidado. La compasión como conocimiento de las mujeres humanitarias en la guerra (1853-1945)', in A. Zarzoso and J. Arrizabalaga (eds.), Al servicio de la salud humana. La historia de la medicina ante los retos del siglo XXI, Ciudad Real: QL Printers, pp. 21-26.

Martín-Moruño, D., Edgar, L. B. and Leyder, M. (2020), 'Feminist perspectives on the history of humanitarian relief (1870-1945)', Medicine, Conflict and Survival, https://doi.org/10.1080/13623699.2020.1717720

Martín-Moruño, D. and Ordóñez, J. (2010), 'The nursing vocation as political participation for women during the Spanish Civil War', Journal of War and Culture Studies, 2:3, pp. 305-21.

Martínez-Vidal, À. (2020), 'The powers of masculinization in humanitarian storytelling: the case of the surgeon María Gómez Álvarez in the Varsovia Hospital (Toulouse, 1944-1950)', Medicine, Conflict and Survival, https://doi.org/10.1080/13623699.2019.1710902

Nash, M. (1986), 'Las mujeres en la Guerra Civil', Historia 16, La Guerra Civil, 14, Sociedad y Guerra, pp. 104-17. 
(1995), Defying Male Civilization: Women in the Spanish Civil War, Denver, Col.: Arden Press.

National Joint Committee for Spanish Relief (1937), 'Spanish Relief Bulletin No.10 of the National Joint Committee, December 1937', Warwick Digital Collections, https://wdc.contentdm.oclc.org/digital/collection/scw/id/13499/

Palfreeman, L. (2012), Salud! British Volunteers in the Republican Medical Service During the Spanish Civil War, 1936-1939, Eastbourne: Cañada Blanch Centre for Contemporary Spanish Studies/Sussex Academic Press.

(2013), Aristocrats, Adventurers and Ambulances British Medical Units in the Spanish Civil War, Eastbourne: Cañada Blanch Centre for Contemporary Spanish Studies/Sussex Academic Press.

Preston, P. (2006), The Coming of the Spanish Civil War. Reform, Reaction and Revolution in the Second Republic, London: Penguin Books.

(2012), The Spanish Holocaust. Inquisition and Extermination in Twentieth Century Spain, London: Harper Press.

Roberts, S. L. (2010), Place, life histories and the politics of relief: episodes in the life of Francesca Wilson, humanitarian educator activist, $\mathrm{PhD}$ thesis, University of Birmingham, https://etheses.bham.ac.uk/id/eprint/848/1/Roberts10PhD A1a.pdf.

Stewart, F. (1942), Dawn Escape, London: Everybody's Books, https://archive.org/details/DawnEscapeFridaStewartEbook

(1944), Unpublished memoir [provisionally entitled Stormy Years].

(1986), Interview with Jon Arrizabalaga, author's private collection.

Taithe, B. (1998), 'The Red Cross flag in the Franco-Prussian War: Civilians, humanitarianism and war in the 'Modern' Age', in R. Cooter, M. Harrison, and S. Sturdy (eds.), War, Medicine and Modernity, Stroud: Sutton, pp. 22-47.

(1999), Defeated Flesh: Welfare, Warfare and the Making of Modern France, Manchester: Manchester University Press.

Thomas, H. (1961), The Spanish Civil War ( $1^{\text {st }}$ ed.), London: Eyre and Spottiswoode.

Webster, R. (2015), “'A Spanish housewife is your next door neighbour”: British Women and the Spanish Civil War', Gender \& History, 27:2, pp. 397-416.

Wilson, F. (1944), In the Margins of Chaos. Recollections of Relief Work in and between Three Wars, London: John Murray.

Young, G. (1937), 'Report for February, March, April, 1937, for the Southern Spanish Relief Committee (SSRC)', Young family archive, courtesy of the current Sir George Young and Lady Aurelia Young. 


\section{CONTRIBUTORS DETAILS}

Dr Linda Palfreeman is a lecturer in the Department of Humanities, University CEU Cardenal Herrera, Elche, Spain. Her chief area of research is the history of medicine and the administration of medical assistance/humanitarian aid during wartime, particularly during the First World War and the Spanish Civil War. This research has led to various publications and participation in seminars, conferences and other events in Spain and internationally. She is currently a member of the state-funded project 'Relief actions and medical technologies in humanitarian emergencies (1850-1950): agencies, agendas, spaces and representations'.

Contact: Department of Education, Universidad CEU Cardenal Herrera, c/Carmelitas, 3, 03203 Elche, Alicante, Spain.

E-mail: palfr.el@uchceu.es

https://orcid.org/0000-0003-2413-601X

Dr Jon Arrizabalaga is a research professor in the History of Science with the Spanish National Research Council (CSIC) at the Milà i Fontanals Institution for Research in Humanities, Barcelona. His areas of expertise include medicine, health and disease in pre-modern Europe, and global health, biomedicine and social movements in the modern world. He is currently working on war, medicine and humanitarianism in Europe from 1850 to 1950 from a transnational and interdisciplinary perspective, and with particular attention to Spain. He has published works on the progress of science during war, humanitarianism and on the international Red Cross movement.

Contact: IMF-CSIC, Carrer de les Egipcíaques, 15, 08001 Barcelona.

E-mail: jonarri@imf.csic.es

https://orcid.org/0000-0002-0740-4951 